\title{
SOME REPRODUCTIVE PARAMETERS OF NON-ADULT, ADULT NON-PREGNANT AND PREGNANT SHE CAMEL SLAUGHTERED IN ASSIUT GOVERNORATE
}

\author{
A. A. Mohammed and G.B. Mahmoud \\ Department of Animal and Poultry Production, Faculty of Agriculture, University \\ of Assiut, Egypt
}

\section{SUMMARY}

The aims of this study were to investigate the anatomy and ovarian activity of camel reproductive tract in addition to determination of glucose and urea concentrations in both serum and follicular fluid. Female reproductive tract $(n=20)$ and blood samples were collected from the slaughtered she camels. Based on the ovarian structures, the reproductive tracts of she camels were classified into nonadult (no corpora lutea or albicantia on the ovaries), adult non-pregnant (corpora albicantia and/or corpora lutea $<4 \mathrm{~g}$ on the ovaries) and pregnant (corpora albicantia and corpora lutea $>4 \mathrm{~g}$ on the ovaries). Blood samples were collected during slaughter process from each animal. Weights of ovaries and corpora lutea were recorded as well as numbers of follicles, corpora lutea and albicantia. The follicles were classified according to their diameter to small $(<0.3 \mathrm{~cm})$ medium $(0.3-$ $0.8 \mathrm{~cm}$ ) and large $(>0.8 \mathrm{~cm})$. Medium and large follicles were aspirated to collect follicular fluids and oocytes. Quality of oocytes was evaluated after classification into cumulus enclosed; partially cumulus enclosed and denuded oocytes. Weight and measurements of reproductive tracts were determined.

The results indicated that ovaries of slaughtered she camels enclosed in an ovarian bursa, had flattened shape, and follicles giving the ovaries the appearance of a bunch of grapes. Weights of ovaries were less $(P<0.05)$ in non-adult animals compared to adult non-pregnant and pregnant ones. Corpora lutea and/or albicantia were found on the right and left ovaries of the adult non-pregnant and/or pregnant animals. She camel has a bicornuate uterus, where the left horn was longer $(P<0.05)$ than the corresponding right one in non-adult, adult non-pregnant and pregnant animals. The length of cervix was $1.9 \pm 0.1,3.2 \pm 0.4 \& 3.7 \pm 0.5 \mathrm{~cm}$ with 3 to 4 rows of outgrowth ridges in non- adult, adult non-pregnant and pregnant animals, respectively. The length of vagina was $4.2 \pm 0.76,21.0 \pm 5.3 \& 26.6 \pm 2.7 \mathrm{~cm}$ in nonadult, adult non-pregnant and pregnant animals, respectively.. Majority of colleted oocytes were cumulus enclosed (66.7\%) whereas the remaining ones were partially cumulus enclosed (25.0\%) and denuded (8.3\%). Urea concentration in serum $(29.3 \pm$ 6.1) was reflected in the follicular fluid $(31.3 \pm 13.4)$.

Keyword: Camel, reproductive tract, ovarian structure and measurement

\section{INTRODUCTION}

Camels are classified as dual purpose in addition to be race animals (Wardeh, 2004). Camels (Camelus dromedarius) contribute in producing milk and meat under pastoral systems in the Afro-Asian dry land belt (Kaufman, 2005). Average of produced milk and meat varies according to species (Wardeh, 2004). Moreover,

Issued by The Egyptian Society of Animal Production 
camels are adopted to produce under scarcity of water, poor quality feed and severe heat stress (El-Wishy, 1988).

Camel milk might play a protective role against tissue damage mediated by free radicals (Al-Humaid et al., 2010). However, the reproductive potentiality should be improved. To exploit the recent techniques (e.g. superovulation, embryo transfer and cloning of camel (Skidmore et al., 1998 and Wani et al., 2010) understanding of the reproductive biology of camels including anatomy of the reproductive tract is required.

Ali et al. (2007) determined serum and follicular fluid concentrations of some biochemical metabolites (glucose, cholesterol, total protein, albumin, globulin and triglycerides) during the low and the peak breeding seasons in she camels in relation to the follicular size. They found no relation between serum and follicular fluid contents of the aforementioned metabolites. Wani and Skidmore (2010) reported that biochemical changes in serum and follicular fluid influenced reproductive outcome. In the light of the previous studies, decrease in serum glucose concentration (Yan et al., 2008) in mice and increase serum urea concentration in sheep (Mohammed et al., 2011) were adversely affected follicle numbers and sizes and oocytes' quality. Iwata et al. (2006) concluded that blood urea nitrogen is a predictable index of the developmental competence of bovine oocytes. Furthermore, Mohammed and Attaai., (2011) found that elevated serum urea retarded timing of embryo cleavage at earlier stages in mice.

The aim of the present study was to characterize the reproductive tracts and ovarian activity of she camel; to find out the relation between follicular fluid and serum contents of urea and glucose concentrations and to evaluate the quality of collected oocytes.

\section{MATERIALS AND METHODS}

\section{Collection of reproductive tracts of female dromedary camels:}

Twenty reproductive tracts of female dromedary camels slaughtered in Assiut governorate were collected during October and November (peak of breeding season). Based on corpora lutea or corpora albicantia observed on the ovaries, the genital tract were classified into non-adult (no corpora structures), adult non-pregnant (corpora albicantia and/or corpora lutea $<4 \mathrm{~g}$ in the ovaries) and pregnant (corpora albicantia and corpora lutea $>4 \mathrm{~g}$ in the ovaries). The collected genital tracts were kept in a cool box $\left(30-33^{\circ} \mathrm{C}\right)$ and transported to the laboratory within 4 hours.

\section{Collection of blood samples:}

Blood sample (about $10 \mathrm{ml}$ ) was collected from all experimental she camels and centrifuged at $400 \mathrm{rpm}$ for 15 minutes for serum separation. Serum was decanted into Eppendrofe tubes and stored at $-20{ }^{\circ} \mathrm{C}$ until the analysis of glucose and urea.

\section{Measurements of reproductive system:}

Weights and length of reproductive tract were recorded. Weight and numbers of follicles on each ovary were recorded as well. The follicles were classified into small $(<0.3 \mathrm{~cm})$; medium $(0.3-0.8 \mathrm{~cm})$ and large $(>0.8 \mathrm{~cm})$ to evaluate the oocytes, which expected to be developed in vitro. Follicles $(\geq 0.3 \mathrm{~cm})$ were aspirated for collection of follicular fluid and oocytes using syringe with a needle of 18-gauge. The collected follicular fluid was stored in Eppendrofe tubes at $-20^{\circ} \mathrm{C}$ for the analysis of glucose 
and urea. Numbers and quality of the collected oocytes were recorded in Ringer's medium supplemented with $10 \%$ serum. Oocytes were categorized into three classes based on the cumulus cells and homogeneity of the cytoplasm (Tornera et al., 2003) as:

Grade 1 (cumulus-enclosed): Oocytes were completely invested with cumulus cell layers (good oocytes).

Grade 2 (partial-enclosed ): Oocytes were surrounded with scantly cumulus cell layers (fair oocytes)

Grade 3 (denuded oocytes): Naked (denuded) oocytes.

Determination of serum glucose and urea concentrations:

Urea and glucose in both serum and follicular fluid were determined calorimetrically using readymade commercial kits (diamond kit, Egypt) according to the method described by the manufacturer.

\section{Statistical analysis:}

Data are presented as means \pm SD. Differences between mean values were determined by ANOVA procedures of SAS (1998) followed by comparisons using the Duncan's multiple range test. Differences with $\mathrm{P}<0.05$ were considered significant.

\section{RESULTS AND DISCUSSION}

Out of twenty reproductive tracts examined, three were for non-adult $(15 \%), 10$ for adult non-pregnant $(50 \%)$ and the rest seven were for pregnant animals $(35 \%)$.

\section{Reproductive tract measurements of non-adult, non-pregnant and pregnant camels:}

Weight of reproductive tracts increased $(\mathrm{P}<0.05)$ with age advancement, from non-adult to adult irrespective of pregnancy, which agree with the findings of Mohammed (2009). Moreover, in pregnancy cases, weight and size of reproductive tract were consequently increased (Plate 1, a-c).

Uterus had bicornuate shape like the letter Y (Plate 1 a-c), The present findings agree with the findings of Arthur et al. (1986), while disagree with the findings of Srikandakumar et al. (2001), who described camel uterus as bipartite type. Uterus length and diameter increased $(\mathrm{P}<0.05)$ from non-adult, non-pregnant and pregnant camels (Plate1 1). Unlike ruminants, the left parts of the reproductive tract of shecamel (oviduct and uterine horn) were longer than the right parts in all ages (Plate 1, a-c). This finding comes close to the findings of Chen and Yuen (1984); Arthur et al. (1986); and Srikandakumar et al. (2001). Arthur et al. (1986) also reported that the left uterine horn is distinctly larger than the right, even in the fetus. The diameter of the left uterine horn was slightly more than the right one and increased during pregnancy, with short uterine body (Table 1).

Two fetuses were collected from the left horn of uterus whereas the two corpora lutea (CLs), were detected on the right ovary, which indicated possibility of redistribution of embryos during pregnancy in cases of twines.(Plate $1 \mathrm{i}$ ). In another case, placenta was collected from the left horn with an area of $900 \mathrm{~cm}^{2}$ (length $\mathrm{x}$ width $50 \times 18.0 \mathrm{~cm}$, respectively) (Plate $1 \mathrm{j}$ ). In the present study, the fetus was solely exists in the left uterine horn which agree with the results of ElWishy (1988), 
Srikandakumar et al. (2001) reporting pregnancy in she-camels is usually occurred in left horn and unlike other ruminants, where implantation can occur in either horns.

Table 1. Characteristics of reproductive tract of non-adult, non-pregnant and pregnant camels

\begin{tabular}{lccc}
\hline Items & \multicolumn{3}{c}{ Slaughtered animal } \\
\hline Physiological status & Non-adult & Non-pregnant & Pregnant \\
\hline Number of reproductive system & 3 & 10 & 7 \\
Weight of reproductive system, & $62.1^{\mathbf{b}} \pm 12.5$ & $434.0^{\mathbf{a}} \pm 164.6$ & $595.7^{\mathbf{a}} \pm 110.9$ \\
Length of right oviduct, cm & $11.0^{\mathbf{b}} \pm 1.0$ & $18.5^{\mathbf{a}} \pm 5.3$ & $20.7^{\mathbf{a}} \pm 5.5$ \\
Length of left oviduct, cm & $13.0^{\mathbf{b}} \pm 1.0$ & $23.7^{\mathbf{a}} \pm 5.5$ & $24.3^{\mathbf{a}} \pm 6.4$ \\
Length of right horn, cm & $4.2^{ \pm} \pm 0.76$ & $6.2 \pm 0.9$ & $11.6 \pm 9.2$ \\
Diameter of right horn in the middle, cm & $2.1^{\mathbf{b}} \pm 0.4$ & $2.7^{\mathbf{a b}} \pm 0.3$ & $5.5^{\mathbf{a}} \pm 3.8$ \\
Length of left horn, cm & $5.7^{\mathbf{b}} \pm 1.32$ & $10.7^{\mathbf{a b}} \pm 2.8$ & $17.7^{\mathbf{a}} \pm 5.0$ \\
Diameter of left horn in the middle, cm & $2.1^{\mathbf{b}} \pm 0.3$ & $3.6^{\mathbf{b}} \pm 0.7$ & $9.4^{\mathbf{a}} \pm 2.3$ \\
Length of uterine body, cm & $2.1^{\mathbf{b}} \pm 0.06$ & $5.9^{\mathbf{a}} \pm 1.1$ & $6.6^{\mathbf{a}} \pm 1.8$ \\
Length of cervix, cm & $1.9^{\mathbf{b}} \pm 0.1$ & $3.2^{\mathbf{a}} \pm 0.4$ & $3.7^{\mathbf{a}} \pm 0.5$ \\
Length of vagina, cm & $4.2^{\mathbf{c}} \pm 0.76$ & $21.0^{\mathbf{b}} \pm 5.3$ & $26.6^{\mathbf{a}} \pm 2.7$ \\
\hline Values are presented as means \pm standard deviation & & \\
a,b,c: Values with the different superscripts on the same row differ at $\mathrm{P}<0.05$ &
\end{tabular}

Ovarian measurements of non-adult, non-pregnant and pregnant camels:

The appearance and size of ovaries vary according to the age and activity of the animals (Table 2). In the non-adult animals they have a smooth surface with visible vesicles $(<3 \mathrm{~cm}$ in diameter) throughout the surface which correspond to the follicles (Plate 1, d). In non-pregnant females the ovaries are oval or circular, flattened laterally and have an irregular surface due to many small follicles. Large follicles and current copora albicantia project from the main contour of the ovary and give it a more lobular form (Plate 1, e). This lobulation increases with increased number of previous ovulations or pregnancies and is mainly due to the presence of old corpora albicantia.

Weight of ovaries were increased $(\mathrm{P}<0.05)$ upon ovulation and formation of corpus luteum (Plate 1, d-g). Weight of ovaries and CLs in pregnant camel was heavier than non-adult and adult ones. In pregnant camel, the right ovary is heavier than the left ovary due to the high number of CLs $(1.6 \pm 0.54)$ than the left one $(1.0 \pm$ 0.0 ) (Table 2). In the seven pregnant she camels, corpora lutea were found in both right and left ovaries. In case of two CLs were found on the same ovary, one of them was larger than the other one (Plate1, f). Copora lutea of the collected reproductive tracts of pregnant animals had a weighs of $4.5-6.7 \mathrm{~g}$. Furthermore, the right $(2.14 \mathrm{vs}$. 1.6) and left (2.85 vs. 0.9) ovaries of pregnant animals, respectively, contained more corpora albicantia than those of non pregnant animals (Table 2and Plate1, d-f). In the non-pregnant camel, Osman (1965) and ElWishy (1992) found that the CL measures $12-15 \mathrm{~mm}$ in diameter and weighs $1.5-2 \mathrm{~g}$ but during pregnancy the size and weight increases to an average of $22 \pm 6 \mathrm{~mm}$ and $4.9 \pm 1 \mathrm{~g}$ respectively.

\section{Ovarian activity of non-adult, non-pregnant and pregnant camels:}

The range numbers of visible vesicular follicles seen on the ovaries of non-adult, non-pregnant and pregnant camels in the present study were 2-5, 10-77 and 44-50 respectively. Although the follicles with diameter $0.3-0.8$ and $>0.8 \mathrm{~cm}$ were not seen on the ovaries of non-adult camel, they were $(4.1 \& 0.4)$ and (3.0 \& 0.4$)$ respectively of non-pregnant and pregnant camels (Table 2). In other studies (Skidmore et al., 1996) the ovarian follicular wave pattern and follicular activity is 
dominated by 4 types of follicles, namely: small growing follicles, mature follicles, regressing follicles or over-large, anovulatory follicles. As the follicular waves overlap with each other, several generations of follicles may be present at the same time (Skidmore et al., 1996). The small growing follicles are visible on the surface of the ovary as small slightly raised vesicles measuring between $2-4 \mathrm{~mm}$, whereas the mature pre-ovulatory follicle measures between $13-20 \mathrm{~mm}$ (Tibary and Anouassi 1996; Skidmore et al., 1996) and is spherical, turgid, with a thin clear translucent wall and protrudes markedly from the ovarian surface (Plate $1 \mathrm{~h}$ ).

The appearance of regressing follicles depends on the stage of regression. At the start of regression the follicular wall becomes thick and opaque and the diameter decreases slowly until the follicle recedes into the ovary itself. Large anovulatory follicles are present in about 50\% of non-mated females and their size and appearance was highly variable (Tibary and Anouassi 1996; Skidmore et al., 1996). They vary in size from $25-60 \mathrm{~mm}$ and may have a thin or thick, opaque wall and contain either serous or haemorrhagic fluid with various amounts of fibrin.

Table 2. Ovarian measurements and activity of non-adult, non-pregnant and pregnant camels

\begin{tabular}{lccc}
\hline Item & \multicolumn{3}{c}{ Slaughtered animal } \\
\hline Physiological status & Non-adult & Non-pregnant & Pregnant \\
\hline Weight of right ovary, g & $0.93^{\mathbf{c}} \pm 0.25$ & $4.04^{\mathbf{b}} \pm 1.13$ & $7.46^{\mathbf{a}} \pm 2.8$ \\
Weight of left ovary, g & $1.09^{\mathbf{b}} \pm 0.24$ & $4.2^{\mathbf{a}} \pm 1.1$ & $4.78^{\mathbf{a}} \pm 2.5$ \\
Size of right ovary, cm & $1.3^{\mathbf{b}} \times 1.1^{\mathbf{b}}$ & $3.02^{\mathbf{a}} \times 2.0^{\mathbf{a}}$ & $2.9^{\mathbf{a}} \times 2.2^{\mathbf{a}}$ \\
& $\times 0.4^{\mathbf{b}}$ & $\times 0.7^{\mathbf{a}}$ & $\times 0.9^{\mathbf{a}}$ \\
& $1.4^{\mathbf{b}} \times 1.1^{\mathbf{b}}$ & $3.6^{\mathbf{a}} \times 2.3^{\mathbf{a}}$ & $3.2^{\mathbf{a}} \times 2.2^{\mathbf{a}}$ \\
Size of left ovary, cm & $\times 0.4^{\mathbf{b}}$ & $\times 0.8^{\mathbf{a}}$ & $\times 0.8^{\mathbf{a}}$ \\
& $2.6 \pm 0.6$ & $22.8 \pm 10.7$ & $25.6 \pm 21.1$ \\
Follicles on the right ovary, $<0.3 \mathrm{~cm}$ & $0.0 \pm 0.0$ & $4.8 \pm 3.22$ & $4.3 \pm 2.7$ \\
Follicles on the right ovary, $0.3-0.8 \mathrm{~cm}$ & $0.0 \pm 0.0$ & $0.1 \pm 0.3$ & $0.0 \pm 0.0$ \\
Follicles on the right ovary, $>0.8 \mathrm{~cm}$ & $3.0 \pm 1.7$ & $35.6 \pm 26.6$ & $26.9 \pm 18.4$ \\
Follicles on the left ovary, $<0.3 \mathrm{~cm}$ & $0.0 \pm 0.0$ & $4.1 \pm 3.44$ & $3.0 \pm 2.4$ \\
Follicles on the left ovary, $0.3-0.8 \mathrm{~cm}$ & $0.0 \pm 0.0$ & $0.4 \pm 0.7$ & $0.4 \pm 0.8$ \\
Follicles on the left ovary, $>0.8 \mathrm{~cm}$ & $0.0^{\mathbf{b}} \pm 0.0$ & $0.0^{\mathbf{b}} \pm 0.0$ & $1.6^{\mathbf{a}} \pm 0.5$ \\
Number of CL on the right ovary & $0.0^{\mathbf{b}} \pm 0.0$ & $0.0^{\mathbf{b}} \pm 0.0$ & $5.5^{\mathbf{a}} \pm 1.0$ \\
Weight of CL on the right ovary & $0.0^{\mathbf{b}} \pm 0.0$ & $0.1^{\mathbf{b}} \pm 0.0$ & $1.0^{\mathbf{a}} \pm 0.0$ \\
Number of CL on the left ovary & $0.0 \pm 0.0$ & $2.1 \pm 0.0$ & $4.6 \pm 0.1$ \\
Weight of CL on the left ovary & $0.0^{\mathbf{b}} \pm 0.0$ & $1.6^{\mathbf{a}} \pm 1.17$ & $2.14^{\mathbf{a}} \pm 1.07$ \\
Number of C. Alb. on the right ovary & $0.0^{\mathbf{b}} \pm 0.0$ & $0.9^{\mathbf{b}} \pm 0.7$ & $2.8^{\mathbf{a}} \pm 1.77$ \\
Number of C. Alb. on the left ovary & & &
\end{tabular}

Values are presented as means \pm standard deviation

a,b,c: Values with the different superscripts on the same row differ at $\mathrm{P}<0.05$

CL: Corpus luteum; C. Alb.: corpora albicantia

Morphology of collected oocytes :

A total of 35 follicles of diameter $\geq 0.3 \mathrm{~cm}$ were aspirated to collect oocytes from non-pregnant and pregnant she camels. Twenty four oocytes were collected with efficiency of $68.6 \%(24 / 35)$. Majority of the collected oocytes were of grade $1(66.7$, $16 / 24)$, whereas the remaining oocytes were either grade $2(25 \%, 6 / 24)$ or grade 3 $(8.3,2 / 24)$ (Fig 1). 


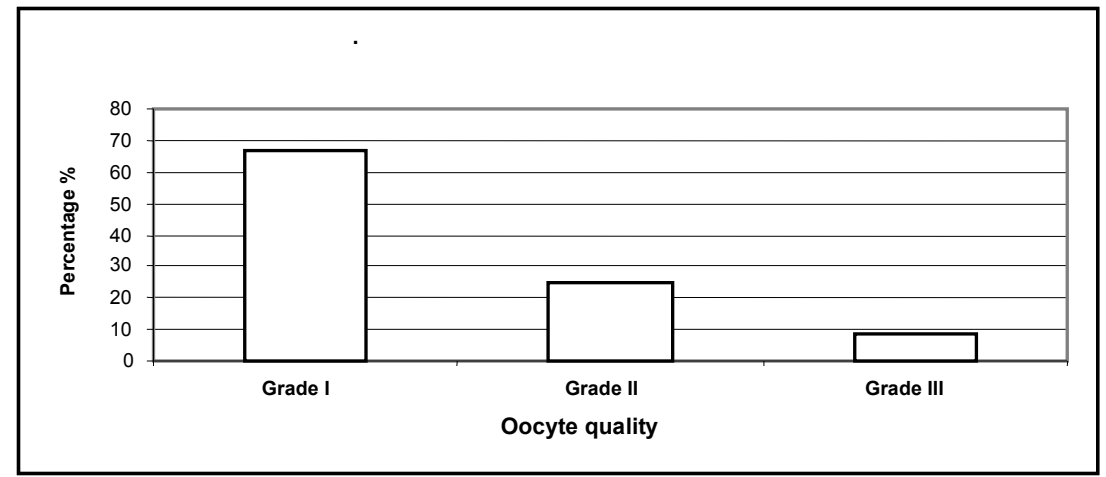

Figure 1: Quality of collected oocytes from the slaughtered she-camels

Tornera et al. (2003) isolated oocytes from sliced ovaries of she camel after slaughtering of non-pregnant and pregnant donors. The morphology of oocytes was divided into COCs with compact (26.9 and 28\%), dispersed (39.3 and 46\%), corona radiata cumulus investment (27.9 and $21.7 \%$ ) and without cumulus (6 and $4.2 \%$ ), respectively for pregnant and non-pregnant donors. The COCs of non-pregnant and pregnant donors with compact and dispersed cumulus cells were collected together in this study $(66.7 \%)$, which is lower than that reported in the previous studies. This might be related to increase or decrease metabolites concentrations such as glucose and urea in serum and follicular fluid. Davoodian et al. (2010) conducted a study to describe in detail the ultrastructural features and morphological characteristics of camel oocytes from preantral follicles in relation to the sequential stages of follicular development and also for oocytes from antral follicles in relation to their diameter. They found that the growth of camel oocyte is associated with progressive increase in the number of granulosa cells, mitochondria, endoplasmic reticulum, Golgi complexes and cytoplasmic vesicles as well as decrease in the number of lipid droplets and the nucleus migration from an eccentric in preantral to a peripheral location in antral follicles.

\section{Urea and glucose concentrations:}

Urea and glucose concentrations in serum and follicular fluid are presented in Table (3) indicating no significant difference in the concentrations of follicular fluids and blood serum. Results of urea concentrations in serum of non-pregnant animals are in agreements with those obtained by Ahmed and Omer (2009). They found that urea and glucose concentrations respectively in camel serum were $28.7 \pm 1.42$ and $162.16 \pm 18.8 \mathrm{mg} / 100 \mathrm{ml}$. This might be explained the low quality of the obtained oocytes in this study. Decrease serum glucose concentration (Yan et al., 2008) was adversely affected follicle number and size as well as oocyte quality. In addition, the adverse effect of urea on the oocyte is likely to involve inhibition in the growth and metabolism of the oocyte-supporting granulosa cells (Rooke et al., 2004). Zia-UrRahman et al. (2008) investigated ovarian follicular fluid and serum biochemical, hormonal, electrolytes and amino acids profiles in female dromedary camel (Camelus dromedarius). This study is indicative of either low or high concentrations of certain biochemical metabolites, hormones, electrolytes and amino acids in small and large 


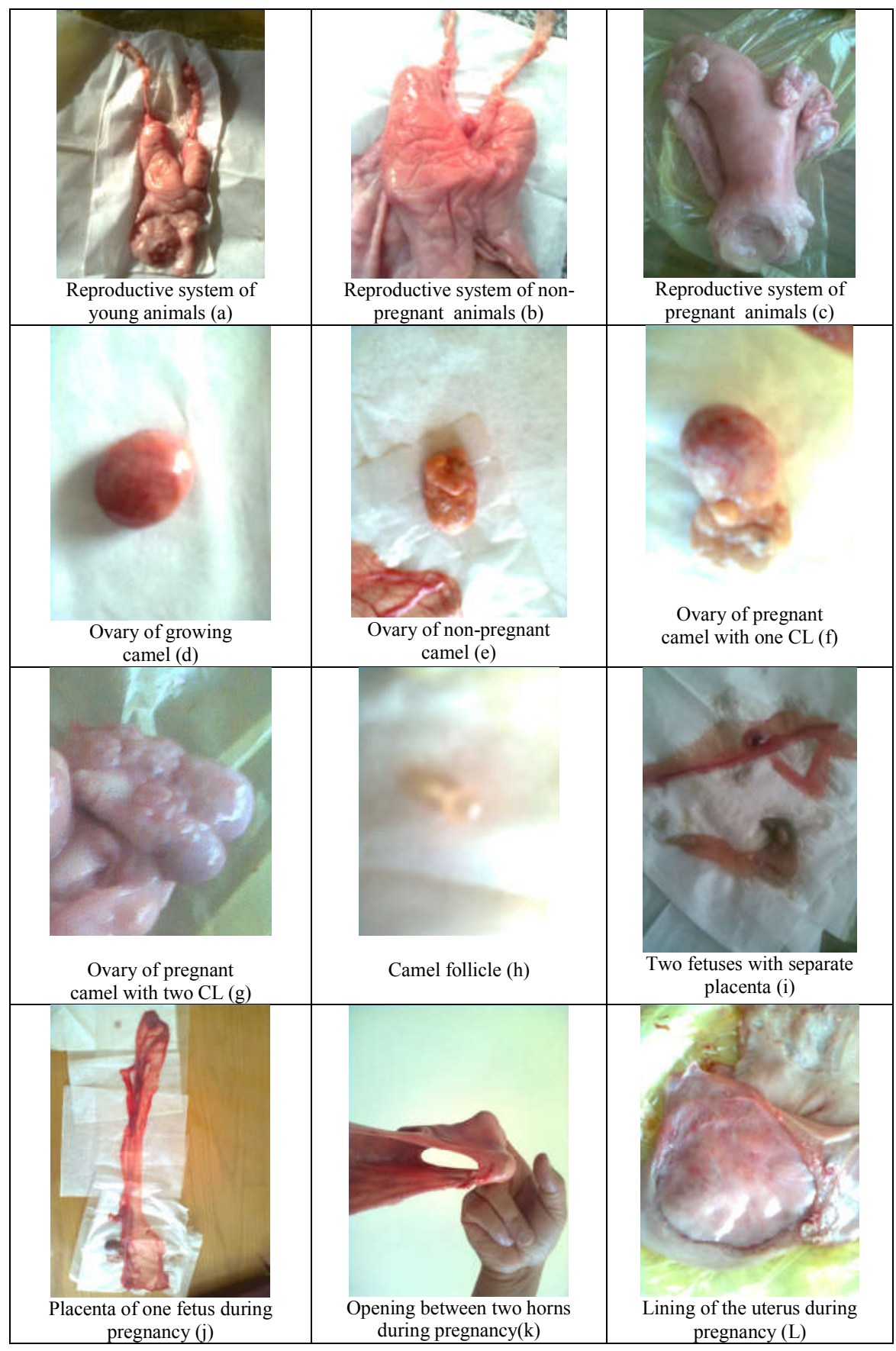

Plate 1. Illustrate the reproductive systems of non-adult, non-pregnant and pregnant she camels 
Table 3. Urea and glucose concentrations ( $\mathrm{mg} / \mathrm{dl})$ in serum and follicular fluid

\begin{tabular}{lcc}
\hline Items & Serum & Follicular fluid \\
\hline Urea & $29.3 \pm 6.1$ & $31.3 \pm 13.4$ \\
Glucose & $66.2 \pm 4.0$ & $70.7 \pm 6.9$ \\
\hline
\end{tabular}

follicles for the individual roles that they play in the growth and development of follicles in the one-humped she-camel

\section{CONCLUSION}

It could be concluded that follicles are found in the slaughtered she-camels, non pregnant and pregnant. Therefore, ovum-pick up of COCs can be applied of life non pregnant and pregnant she-camels. The collected COCs could be used for in vitro production of embryos (IVP). Transfer of blastocysts in she-camel should be done to the left side of uterus. Studies of in vitro production of embryo, freezing and vitrification of embryos are still required.

\section{REFERENCES}

Ahmed S.H. and S.A. Omer, 2009. Some normal constituents in serum and cerebrospinal fluid in Sudanese camels (CAMELUS DROMEDARIES). Assiut Vet. Med. J., 55: 123.

Al-Humaid A.I., H.M. Mousa, R.A. El-Mergawi and A.M. Abdel-Salam, 2010. Chemical Composition and Antioxidant Activity of Dates and Dates-Camel-Milk Mixtures as a protective Meal against Lipid Peroxidation in Rats. Am. J. Food Tech., 5 (1): 22-30.

Ali S, N. Ahmad, N. Akhtar, Zia-ur-Rahman and D.E. Noakes, 2007. Metabolite contents of blood serum and fluid from small and large sized follicles in dromedary camels during the peak and the low breeding seasons. Anim. Reprod. Sci., 108(3-4): 446-456.

Arthur G.H., A.T. Al-Rahim and A.S. Al-Hindi, 1986. Reproduction and genital diseases of the camel. In: A. Higgins (ed), pp. 111-120. "The camel in health and diseases". Bailliere Tindall, London.

Chen B.X. and Z.X. Yuen, 1984. Reproductive pattern of the Bactrian camel. In: Cockrill, W.R. (Ed.) The Camelid, an all-purpose animal. Scand. Inst. Afric. Studies, Uppsala Sweden; 364-386.

Davoodian N., F. Mesbah and M. Kafi, 2010. Oocyte Ultrastructural Characteristics in Camel (Camelus dromedarius) Primordial to Large Antral Follicles. Anat. Histol. Embryol., Nov 24. [Epub ahead of print].

ElWishy A.B., 1992. Functional morphology of the ovaries of the dromedary camel. In: Proceedings of the 1st Int. Camel Conf Dubai, UAE. Allen WR,. Higgins AJ, Mayhew IG, Snow DH and Wade JF Eds. Newmarket: R \& W Publications 149154.

ElWishy A.B., 1988. A study of the genital organs of the female dromedary (Camelus dromedarius). J. Reprod. Fert., 82: 587-593.

Iwata H. J., J. Inoueb, K. Kimurac, T. Kugea, T. Kuwayamaa, Y. Monji, 2006. Comparison between the characteristics of follicular fluid and the developmental competence of bovine oocytes. Anim. Reprod. Sci., 91: 215-223. 
Kaufman B.A., 2005. Reproductive performance of camels (Camelus dromedarius) under pastoral management and its influence on herd development. Livestock Prod. Sci., 92: 17-29.

Mohammed AA., 2009. Ovarian morphology and oocyte quality of ruminant animals in relation to in vitro embryos production. Assiut J. Agric. Sci., 4:1-12.

Mohammed A.A. and A.H. Attaai, 2011. Effects of dietary urea on timing of embryo cleavages and blood components in mice. Vet. World, 4(8):360-363.

Mohammed A.A., G.A. Abdel-Hafez and H.M.S. Ziyadah, 2011. Effect of dietary urea level on ovarian morphology and oocyte quality during follicular and luteal phases in ewes. Egyptian J. Anim. Prod. (Submitted).

Osman A., 1965. Anatomical study of the female genital system of the one-humped camel (Camelus dromedarius) I. The ovaries. S.J.Vet. Sci. Anim. Husb., 6: 41-52.

Rooke J.A., M. Ewen, K. Mackie, M.E. Staines, T.G. McEvoy, and K.D. Sinclair, 2004. Effect of ammonium chloride on the growth and metabolism of bovine ovarian granulosa cells and the development of ovine oocytes matured in the presence of bovine granulosa cells previously exposed to ammonium chloride. Anim. Reprod. Sci., 84: 53-71.

SAS, 1998. SAS User's guide: Statistics.S AS Inst. Inc., Cary, NC, Releigh.

Skidmore J.A., G. R. Starbuck, G.E. Lamming and W.R. Allen, 1998. Control of luteolysis in the one-humped camel Camelus dromedaries). J. Reprod. Fert., 114(2): 201-209.

Skidmore J.A., M. Billah and W.R. Allen, 1996. The ovarian follicular wave pattern and induction of ovulation in the mated and non mated one-humped camel. J. Reprod. Fert., 106: 185-192.

Srikandakumar A. and E.H. Johnson, O. Mahgoub, I.T. Kadim and D.S. Al-Ajmi, 2001. Anatomy and histology of the female reproductive tract of the Arabian camel. Emir J. Agric. Sci., 13: 23-26.

Tibary A. and A. Anouassi, 1996. Ultrasonographic changes of the reproductive tract in the female camel (Camelus dromedarius) during the follicular cycle and pregnancy. J Camel Pract. Res., 3: 71-90.

Tornera H., B. Heleilab, H. Alma, I.M. Ghoneimc, V. Srsend, W. Kanitza, A. Tuchscherera and E.M. Fattouhb, 2003. Changes in cumulus-oocyte complexes of pregnant and non-pregnant camels (Camelus dromedarius) during maturation in vitro. Theriogenol., 60 (5): 977-987.

Wani N.A. and J.A. Skidmore, 2010. Ultrasonographic-guided retrieval of cumulus oocyte complexes after super-stimulation in dromedary camel (Camelus dromedarius). Theriogenol., 74(3): 436-442.

Wani N.A., U. Wernery, F.A.H. Hassan, R. Wernery, and J.A. Skidmore, 2010. Production of the First Cloned Camel by Somatic Cell Nuclear Transfer. Biol Reprod., 82: 373-379.

Wardeh M. F., 2004. Classification of the Dromedary Camels. J. Camel Sci. 1: 1-7.

Yan J., B. Zhou, J. Yang, P. Tai, X. Chen, H. Zhang, M. Zhang and G. Xia, 2008. Glucose can reverse the effects of acute fasting on mouse ovulation and oocyte maturation. Reprod Fertil Dev., 20(6):703-712.

Zia-Ur-Rahman S.A. Bukhari, N. Ahmad, N. Akhtar, A. Ijaz, M.S. Yousaf and I.U. Haq, 2008. Dynamics of follicular fluid in one-humped camel (Camelus dromedarius). Reprod. Domest. Anim., 43 (6): 664-671. 


\title{
بعض القياسات التتاسلية لإناث الجمال غير البالغة والبالغة غير العثار والعشار المذبوحة بمحافظة أسيوط
}

\author{
عبد الناصر أحمد محمد ، جمال بلري محمود \\ قسم الإنتاج الحيوانس واللدواجن، كلية الزراعة، جامعة أسيوط، أسبيوط
}

الهدف من هذه الدراسة هو تقدير بعض القياسات للقناة التناسلية ونشاط المبيض لإنات الجمال المذبوحة

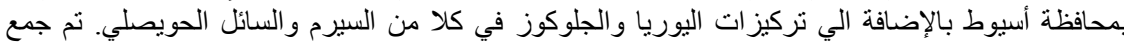

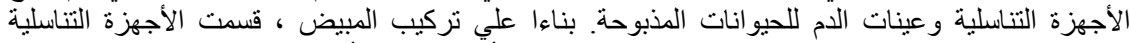

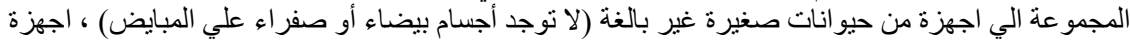

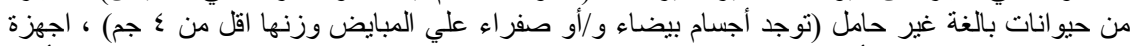

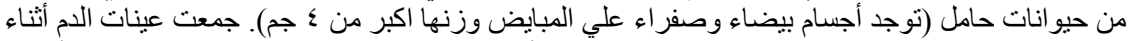

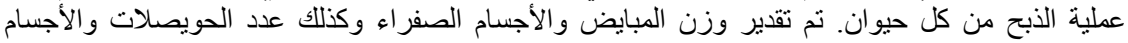

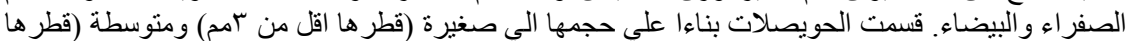

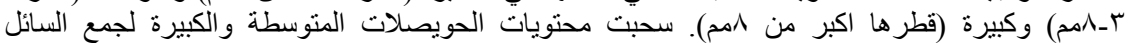

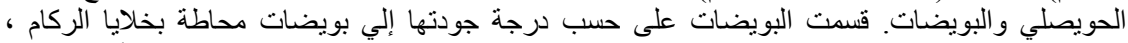

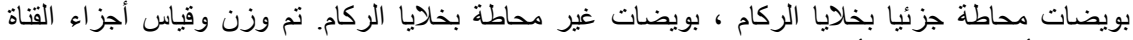

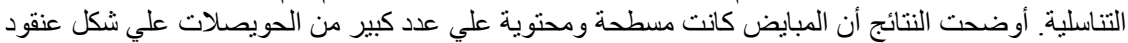

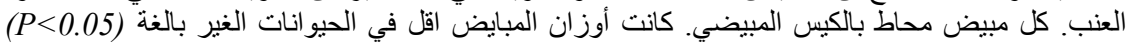

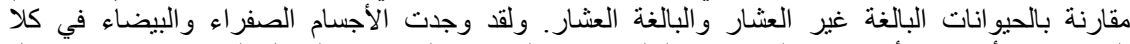

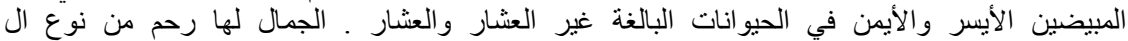
Bicornuate

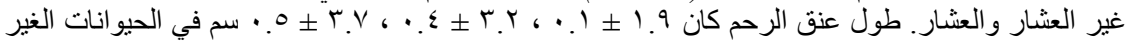

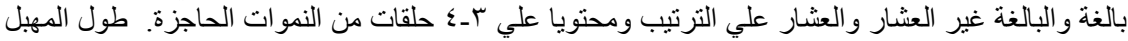

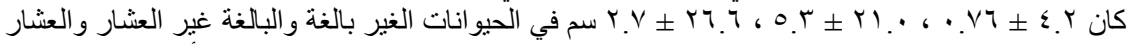

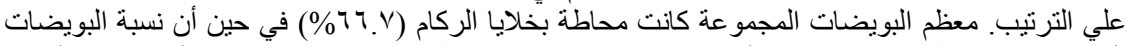

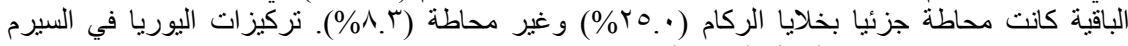

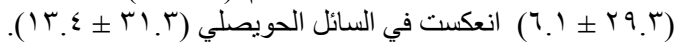

